\title{
Anatomical and ultrastructural aspects of root and mycorrhiza of Anadenanthera peregrina (L.) Speg. var.falcata (Benth.) Altschul (Leguminosae-Mimosoideae) $^{1}$
}

\author{
EDUARDO GROSS ${ }^{2,4}$, LÁZARA CORDEIRO3 ${ }^{3}$ and FLÁVIO H. CAETANO
}

(received: August 23, 2002; accepted: September 18, 2003)

\begin{abstract}
Anatomical and ultrastructural aspects of root and mycorrhiza of Anadenanthera peregrina (L.) Speg. var. falcata (Benth.) Altschul (Leguminosae-Mimosoideae)). A. peregrina var. falcata form mutualistic symbiosis with arbuscular mycorrhizal fungus. An anatomical and ultrastructural study was carried out to analyze some aspects of this simbiotic association as well as some root features. The results evidenced the presence of fibers with non-lignified thicked secondary walls in the stele and sparse papillae on root surface. A. peregrina var. falcata mycorrhizas presented features of Arum-type (intercellular hyphae) and Paris-type (extensive coils) arbuscular mycorrhiza. Their general appearance with extraradical hyphae, intracellular coils, intercellular hyphae and arbuscules, is in agreement with arbuscular mycorrhizas of several plants. The ultrastructural observations showed that in intercellular hyphae and arbuscules vacuoles were dominant and that in rough endoplasmatic reticulum and small vesicles seems to be associated with arbuscule senescence process.
\end{abstract}

Key words - Anadenanthera peregrina var. falcata, anatomy, mycorrhiza, root, ultrastructure

RESUMO - (Aspectos anatômicos e ultra-estruturais da raiz e micorriza arbuscular de Anadenanthera peregrina (L.) Speg. var. falcata (Benth.) Altschul (Leguminosae-Mimosoideae)). A. peregrina var. falcata forma simbiose mutualista com fungos micorrízicos arbusculares. Um estudo anatômico e ultra-estrutural analisou alguns aspectos dessa associação simbiótica bem como algumas características da raiz. Os resultados evidenciaram a presença de fibras com parede secundária espessadas não lignificadas no cilindro vascular e a presença de papilas esparsas na superfície da raiz. As micorrizas de A. peregrina var. falcata apresentaram características de micorriza arbuscular do tipo Arum (presença de hifas intercelulares) e do tipo Paris (presença de enovelamento de hifas). Seu aspecto geral com hifas extraradiciais, enovelamentos intracelulares de hifas, hifas intercelulares e arbúsculos seguiu o padrão encontrado nas micorrizas arbusculares de várias plantas. As observações ultraestruturais demonstraram que as hifas intercelulares e os arbúsculos são bastante vacuolizados e que o retículo endoplasmático rugoso e pequenas vesículas parecem estar associados com o processo de senescência do arbúsculo.

Palavras-chave - Anadenanthera peregrina var. falcata, anatomia, micorriza, raiz, ultra-estrutura

\section{Introduction}

Several plants of Brazilian cerrado present symbiotic relationship with arbuscular mycorrhizal fungi (Thomazini 1974). Amongst these plants is Anadenanthera peregrina var. falcata (popularly called "angico do cerrado") an important woody leguminous tree (Lorenzi 1994) that occurs in several regions of Brazilian cerrado. The mutualistic relationships between "angico do cerrado" and these fungi can help in plant adaptation to the Brazilian cerrado environment, which usually present soils deficient in several nutrients (Reatto et al. 1998). Thus the presence

\footnotetext{
1. Part of the PhD thesis of the first author.

2. Universidade Estadual de Feira de Santana, Departamento de Ciências Biológicas, Caixa Postal 252-294, 44031-460 Feira de Santana, BA, Brazil.

3. Universidade Estadual de Paulista, Instituto de Biociências, Caixa Postal 199, 13506-900 Rio Claro, SP, Brazil.

4. Corresponding author: edugross@ rc.unesp.br
}

in roots of the arbuscular mycorrhizal fungi can facilitate the phosphorus and others nutrients uptake, and in turn the plant supplies carbon to the fungal partner.

The structural characteristics of arbuscular mycorrhizal association have been documented extensively (Peterson \& Bonfante 1994). Fungus colonizes the root cortex intercellularly and intracellularly forming hyphae, coils or arbuscules (Scannerini \& Bonfante 1983). Arbuscules are profusely branched structures formed inside the host root cortical cell wall but outside its protoplast (Alexander et al. 1988), since the host plasmalemma invaginates and proliferates around the developing fungus (Bonfante \& Perotto 1995). These fungal structures have been proposed as the preferential site for plant-fungal nutrient exchange (Smith \& Smith 1990). Despite of well documented, studies on arbuscular mycorrhiza have concerned on crop plants such as corn, leeks, beans and onions that are morphologically similar, and the diversity of arbuscular mycorrhizas that may exist in nature remains 
relatively unexplored (Widden 1996). Thus, for example, there are no ultrastructural studies on tropical woody legumes. The aim of the present study was to investigate the anatomy and ultrastructure of the symbiosis between the woody legume Anadenanthera peregrina var. falcata and arbuscular mycorrhizal fungi, as well as some root characteristics.

\section{Material and methods}

Seeds and potting - Seeds of Anadenanthera peregrina (L.) Speg. var. falcata (Benth.) Altschul (LeguminosaeMimosoideae) obtained from Instituto Florestal of São Paulo were surface sterilized and planted in $6 \mathrm{~L}$ pots with Brazilian cerrado soil collected from Corumbataí Brazilian cerrado reserve $\left(22^{\circ} 15^{\prime} \mathrm{S}\right.$ and $47^{\circ} 00^{\prime} \mathrm{W}, 810 \mathrm{~m}$ asl $)$ and maintained in greenhouse. Mycorrhizal colonization of the "angico do cerrado" plants were spontaneous occurring with native arbuscular mycorrhizal fungi present in the soil.

Growth conditions and harvesting - The experiment was conduced from April 2000 to January 2001 in a greenhouse, under natural daylight with average maximum and minimum temperatures $33 \pm 5$ and $14 \pm 5^{\circ} \mathrm{C}$, respectively. Plants were harvested at 10 months, and samples of roots were collected and fixed.

Staining and observation of mycorrhizal and root structure To observe the structure of "angico do cerrado" mycorrhizas, samples of roots were cleared and stained (Phillips and Hayman 1970), mounted on slides and observed using an Olympus BX40 microscope and photographed on Ilford Pan F plus film Asa 50. For root anatomy, many fresh roots were hand-sectioned, stained with Astra blue and safranin, according to Bukatsch (1972) modified apud Kraus \& Arduin (1997) and viewed in same microscope.

Light and electron microscopy - Samples of lateral roots in different stages of development were collected from the plants at 10 months and fixed in glutaraldehyde $2.5 \%$ with sodium phosphate buffer $0.1 \mathrm{M}$ ( $\mathrm{pH} 7.2$ ). The samples were rinsed in phosphate buffer, post-fixed in $1 \%$ osmium tetroxide for $1 \mathrm{~h}$, stained with $2 \%$ uranyl acetate solution for $2 \mathrm{~h}$, dehydrated in graded acetone series, and embedded in a series of Spurr resin (Spurr 1969) and acetone 1:5, 1:3, 1:1, 3:1, 5:1 (v/v) for a extended period with agitation, since these roots are relatively difficult to infiltrate properly. The same samples were used for light microscopy (LM) and transmission electron microscopy (TEM). For LM $1 \mathrm{~mm}$ sections were cut in a Sorvall MT2-B ultra-microtome and stained with $1.5 \%$ methylene blue and $1.5 \%$ azure II. For TEM ultra-thin sections $(60-90 \mathrm{~nm})$ were stained with $2 \%$ ethanolic uranyl acetate for $20 \mathrm{~min}$, and with aqueous lead citrate for 10 min, observed in a Philips CM 100 transmission electron microscope at $80 \mathrm{kV}$, and photographed using Kodak Eastman Motion Picture film.

For scanning electron microscopy (SEM) roots fixed in $2.5 \%$ glutaraldehyde with $0.1 \mathrm{M}$ sodium phosphate buffer were dehydrated in a graded acetone series to absolute, mounted on stubs, coated with gold and carbon in a Balzers SCD 050 sputter coater and viewed with a Philips SEM 505 at $12 \mathrm{kV}$ using Fuji Neopan SS film to record the images.

\section{Results}

Approximately 64 root segments collected from 10 month old plants were analyzed by light and electron microscopy. In LM lateral roots of "angico do cerrado" are usually triarch, composed by a parenchymatous cortex, which is delimited centripetally by endodermis, and centrifugally by an epidermal layer. In the stele, groups of phloem cells alternate with the primary xylem poles and fibers, probably formed by pericycle divisions (figure 1). These fibers are ticked-walled (figure 2) and are very difficult to infiltrate properly with resin (figure 3). "Angico do cerrado" root posses sparse epidermic papillae (figure 4) and sometimes a conspicuous mycorrhizal colonization is observed on it surface (figure 5). In the outer cortical cells of these colonized roots, fungus forms intracellular hyphae and coils (figures 6-8) and in the inner layers of these cells some arbuscules can be seen (figure 8).

In TEM observations of the cortical cells presented several vacuoles with their narrow cytoplasm in periphery and surrounded intracellular hyphae and arbuscules (figures 9-12). Wall of intracellular hyphae is ticker than arbuscule cell wall and both fungal structures posses many vacuoles (figures 9, 10). Intercellular hyphae may be seen in the cortex, they are often vacuolated (figures 9, 11) and usually only one per intercellular space (figure 9), although there may be as many as five in one intercellular space (figure 11).

Section through arbuscule shows its fine hyphal branches and a large vacuolated hypha, which is the arbuscule trunk, in the plant cell (figure 12). In these fine hyphal branches vacuoles are frequently observed (figures 12-14), while few organelles such as mitochondria (figure 14) and nucleus (figure 16) are evidenced. The host cytoplasm are dense (figures 10, 12-18) contains many mitochondria (figures 10, 12-14), rough endoplasmatic reticulum (figures 12-14, 16), ribosomes (figures 14, 16) and some plastids (figures 10, 12-15). Cortical cells with well-developed arbuscule have polymorphic, sometimes lobed, nucleus (figures 12, 13), which posses few heterochromatin (figures 13, 14). Sometimes the system of rough endoplasmatic reticulum is evident, most localized near from fine arbuscule branches (figures 13, 15). 

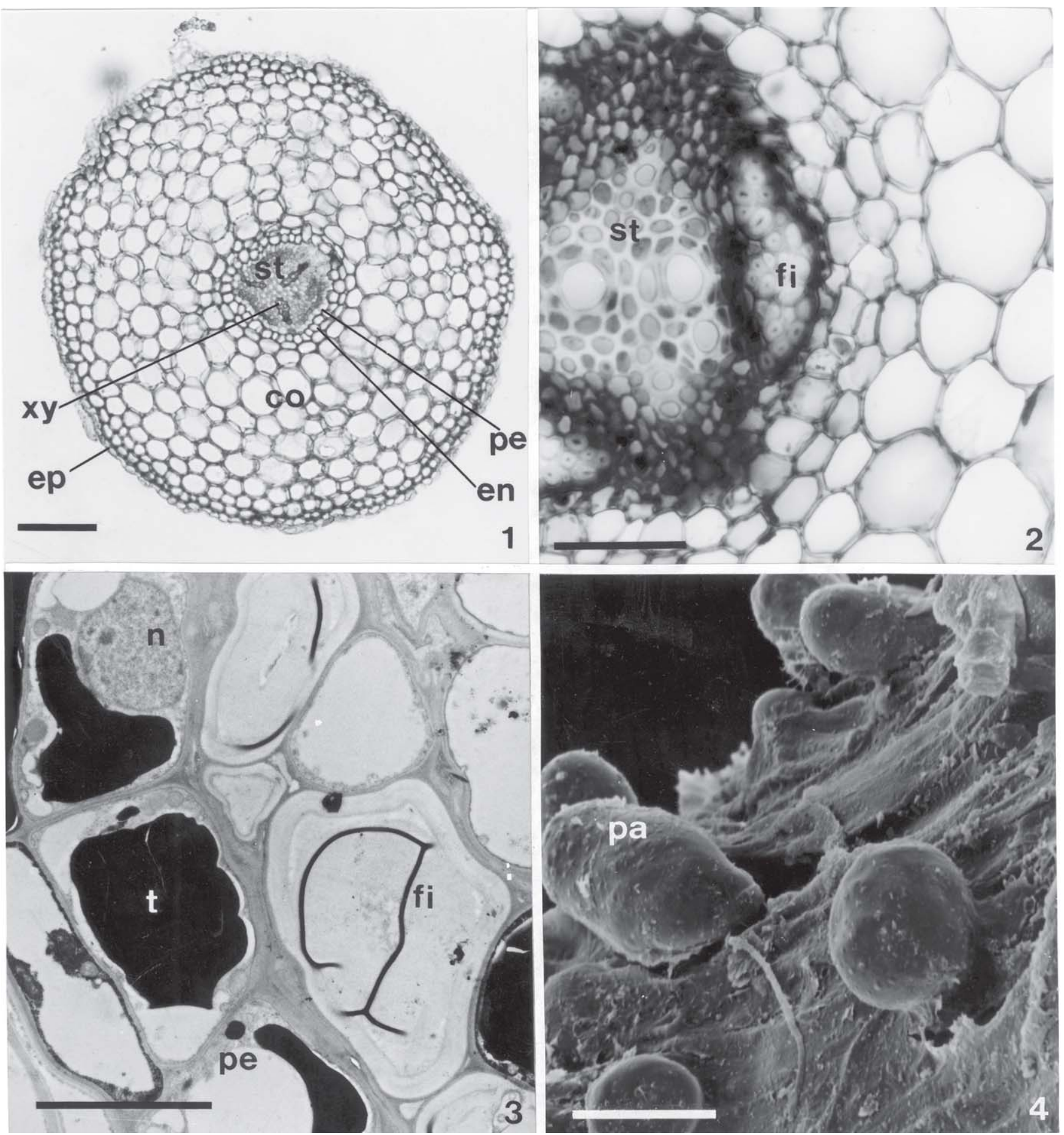

Figures 1-4. Anadenanthera peregrina var. falcata roots. 1. Light micrograph (LM) of a lateral root transversally sectioned to illustrate its structure: epidermis (ep), cortex (co), endodermis (en) and stele (st) with pericycle (pe), xylem cells (xy). 2. LM in higher magnification to observe a group of fibers (fi) in the stele (st). 3. Transmission electron micrograph (TEM) of fibers (fi) beneath the pericycle cells (pe) that contains nucleus (n) and tanins (t). 4. Scanning electron micrograph (SEM) of the superficies showing the papillae (pa). Bars $=0.1 \mathrm{~mm}(1), 30 \mu \mathrm{m}(2), 5 \mu \mathrm{m}$ (3), $20 \mu \mathrm{m}$ (4). 

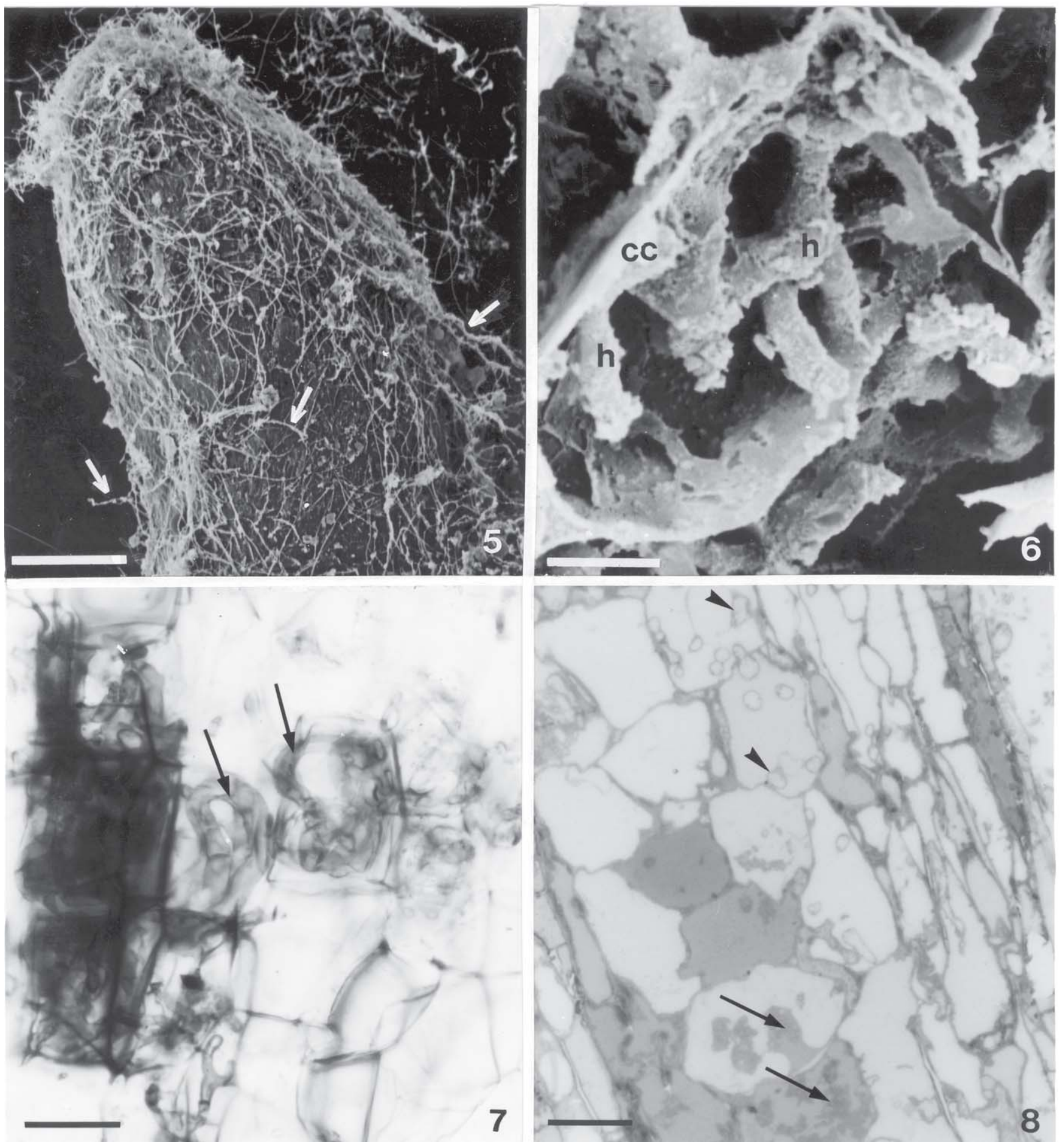

Figures 5-8. Mycorrhizal roots of A. peregrina var. falcata. 5. SEM of conspicuous hyphae (arrows) in superficies of lateral root. 6. SEM of a cortical cell (cc) colonized by fungus hyphae (h). 7. LM of outer cortex region with cells colonized by hyphal coils (arrows). 8. LM of root longitudinally sectioned showing intercellular hyphae (arrowheads) in the outer cortex and arbuscules (arrows) in the inner cortex. Bars $=0.1 \mathrm{~mm}(5), 10 \mu \mathrm{m}(6), 20 \mu \mathrm{m}(7), 30 \mu \mathrm{m}(8)$. 

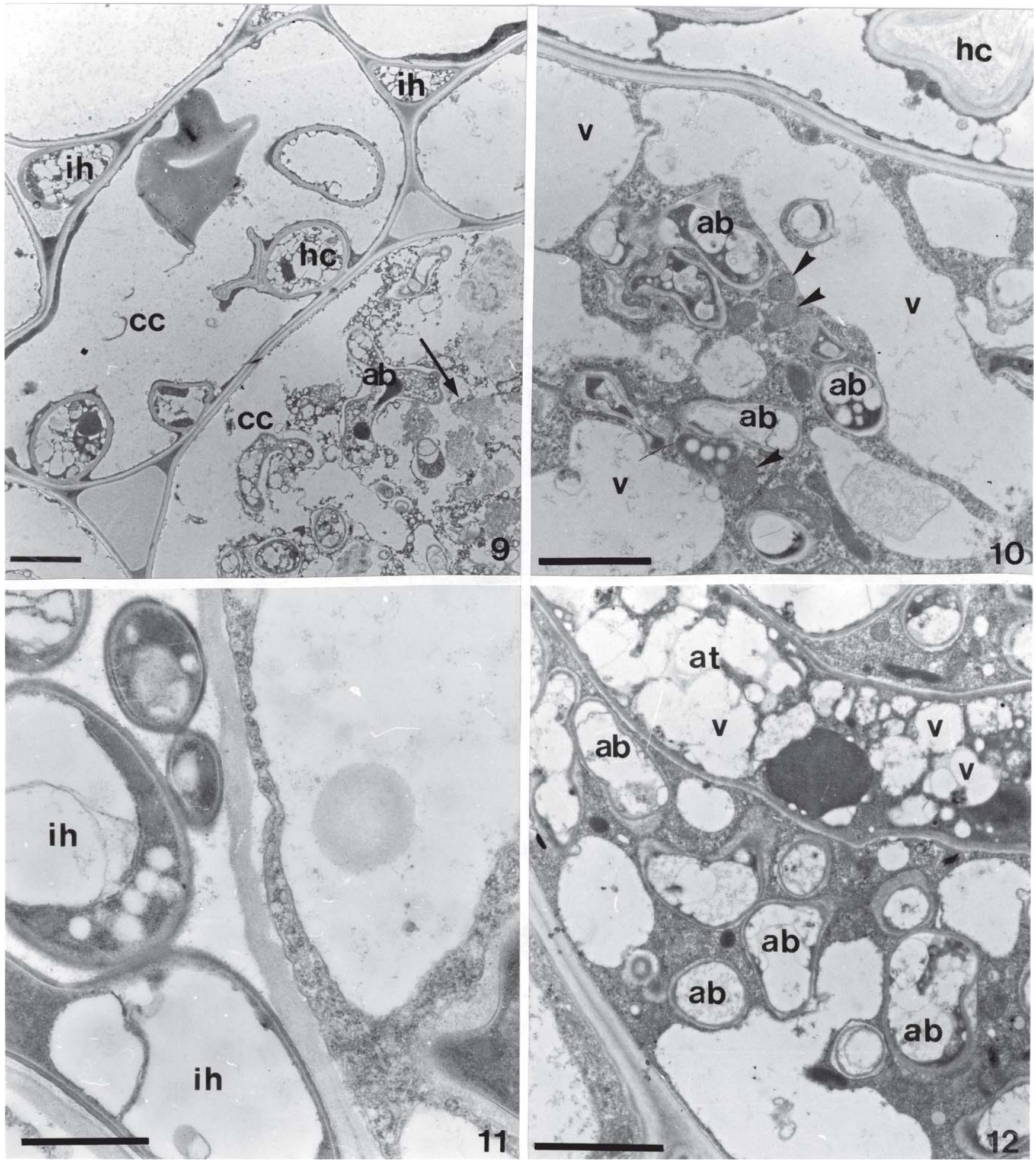

Figures 9-12. TEM of A. peregrina var. falcata cortex colonized by arbuscular mycorrhizal fungus. 9. Low magnification of cortical cells (cc) showing a hyphal coil (hc), intercellular hyphae (ih) and arbuscule branches (ab) sometimes collapsed (arrow). 10. In the dense host cytoplasm that surround the arbuscule branches (ab) mitochondria (arrowheads) can be seen and several vacuoles (v) are present. Note the difference between the hypha coil (hc) wall and arbuscule wall. 11. Sometimes many intercellular hyphae (ih) can be seen in the same space. 12. A vacuolated (v) arbuscule trunk (at) and many arbuscule branches (ab) surrounded by host cytoplasm. Bars $=5 \mu \mathrm{m}$ (9), $3 \mu \mathrm{m}$ (10), $1 \mu \mathrm{m}$ (11), $3 \mu \mathrm{m}$ (12). 
Arbuscules in different stages of development and senescence (figures 9,20) were only generally found in the inner three layers of cortex next to the endodermis (figure 6). The TEM observations show stages of arbuscule degeneration (figures 15, 17, 20). The finer hyphae start the collapse become small, apparently increasing the interface space between the fungal wall and the host membrane, where appear many small vesicles (figures 15, 17, 18). Afterwards fine branches compacted into small masses of wall material (figures $18,19)$ and in the ultimate stage of degeneration the collapse of hypha formed clumps, dense masses of wall material, in the host cytoplasm (figure 20).

\section{Discussion}

Some considerations about root anatomy of "angico do cerrado" were pointed in Cordeiro \& Beltrati (1989) study and the root of this species presents common characteristics to the dicotyledonous in general (Fahn 1990). An unusual feature not previously cited and that was observed in present study, was the presence in stele of groups of fibers, probably arise from pericycle, that posses a thick non-lignified secondary wall. In an anatomical study on Brasilia sickii G.M. Barroso, similar fibers with cellulosic secondary walls were described in its roots and xylopodium (Paviani 1977). The fibers could be related with water storage in these plants that produce xylopodium (Paviani 1974), which is an anatomic complex organ (Appezzato-da-Glória \& Estelita 2000) that provide water and food reserves to the shoots (Rizzini \& Heringer 1961). The function of these fibers, however, needs to be investigated and more substantial evidences are necessary to support this hypothesis since, for example, the roots and xylopodia of Mandevilla illustris (Vell.) Woodson and $M$. velutina $\mathrm{K}$. Schum. not presented same cells in their steles (Appezzato-da-Glória \& Estelita 2000). In the fibers and in the "angico do cerrado" roots in general, there were some difficulties in achieving adequate fixation and resin infiltration, mainly due high levels of lignin, suberin, tannins and polyphenolic materials in tissues.

"Angico do cerrado" present features of Arumtype (intercellular hyphae) and Paris-type (extensive coils) of arbuscular mycorrhiza (AM), and follows the criteria used by Smith \& Smith (1997) it can be considered as intermediate type of AM. The general appearance of these A. peregrina var. falcata mycorrhizas, with external hyphae, intracellular coils, intercellular hyphae and arbuscules, is in agreement with observations on arbuscular mycorrhizas of several plants (Scannerini \& Bonfante 1983). However, the morphology of the intermediate type of AM in A. peregrina var. falcata contrasts with the Arum-type morphology, typical of the most part of crop plants studied. The coils of the "angico do cerrado" AM grow from one cell to the next and together with intercellular hyphae allow fungus spread through the root cortex. In our study AM fungi presented auxiliary cells and do not form vesicles, therefore these fungi are members of the Gigasporineae suborder.

In the outer layers of cortical cells, hyphal coils were formed while in the inner three layers of cortex arbuscules were present and intercellular hyphae were observed anywhere in the cortex. This situation is similar to that reported by Holley \& Peterson (1979) in VAM of beans. Arbuscules starts as a trunk that becomes profusely branched (Bonfante \& Perotto 1995). Arbuscules branches have a thinner (20-30 nm) wall (Peterson \& Bonfante 1994) than not ramified hyphal coils (Kinden \& Brown 1975). The cytoplasm of arbuscules branches in cortical cells of "angico do cerrado" contains few organelles and vacuoles are dominant in these fungal structures.

The invagination of plant membrane and the fungal cell surface create a new and complex compartment composed by the fungal wall and membrane, interfacial material and host plasmalemma (Bonfante \& Perotto 1995). In high pressure/freeze substituted samples, the host membrane is close to the fungal wall, delimiting a narrow space $(80-100 \mathrm{~nm})$ for this compartment (Bonfante \& Perotto 1995), which appears much wider in our conventionally fixed samples. It is assumed that this compartment has a fundamental role in to allow a two-way transfer of nutrients and inorganic elements (Smith \& Smith 1990).

As observed in bean roots (Holley \& Peterson 1979), most of the arbuscules in actively colonized segments of "angico do cerrado" roots show some evidence of deterioration. Brundrett et al. (1985) estimated the duration of these ephemeral fungal structures in 4 to 5 days. The pattern of arbuscule collapse in "angico do cerrado" mycorrhiza is consistent with observations made on the other arbuscular mycorrhizas (Scannerini \& Bonfante 1983). The thinner arbuscule branches are the first to degenerate with the progressive loss of the fungal cytoplasm, increase in the vacuoles and collapse of the hyphae that form residual clumps. Numerous small vesicles are evident in the wider space between host plasmalemma and fungus wall in "angico do cerrado" mycorrhiza and, 

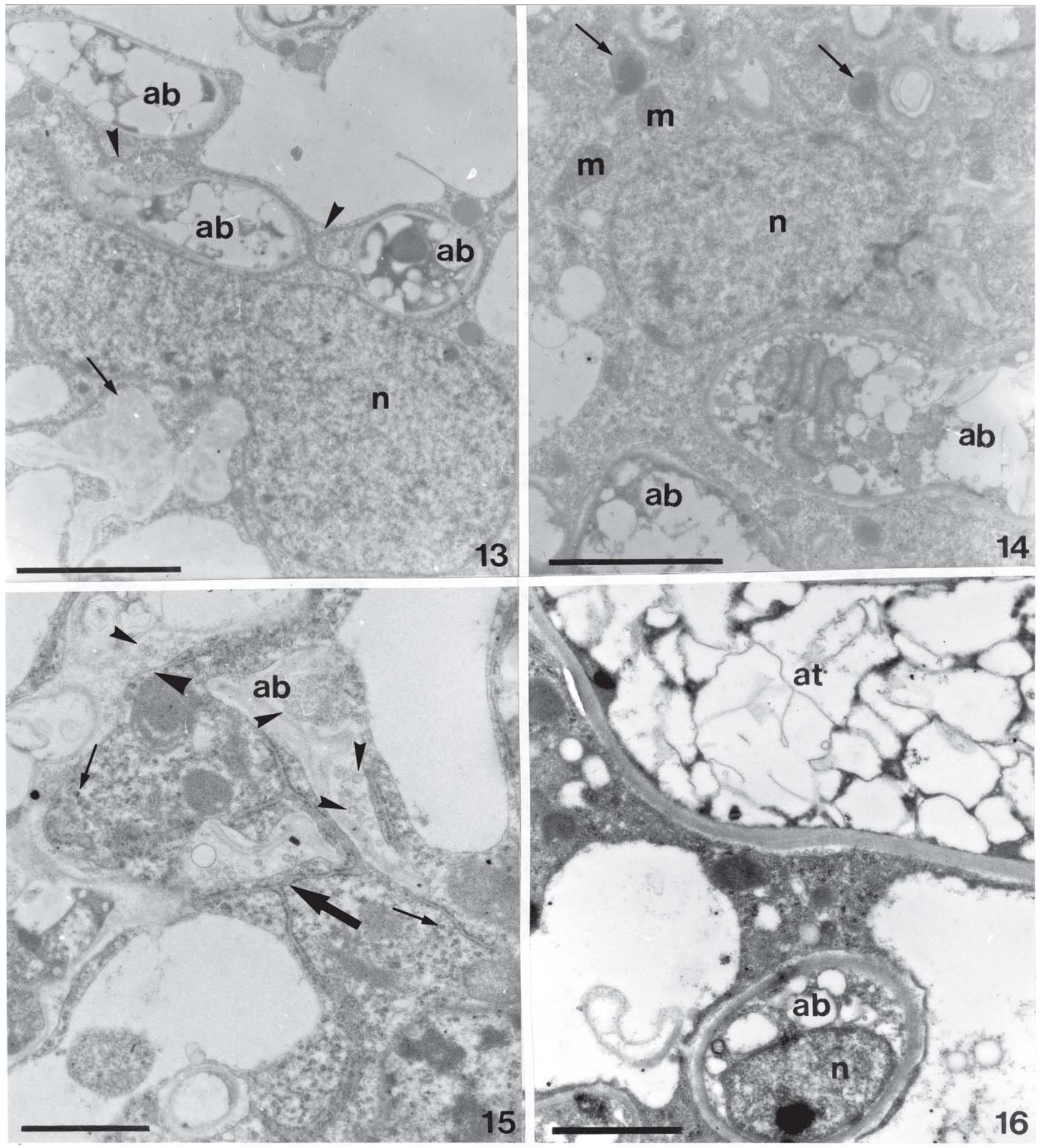

Figures 13-16. TEM of A. peregrina var. falcata cortical cells containing arbuscules. 13. Lobed host nucleus (n) apparently without heterochromatin and endoplasmatic reticulum (arrowheads) close to arbuscule branches (ab), which can be collapsed (arrow). 14. Arbuscule branches (ab) surrounded by host cytoplasm that presents many organelles such as plastids (arrows). Host nucleus (n) and some mitochondria (m) in a arbuscule branch also can be seen. 15. Ribosomes free in host cytoplasm (small arrows) and a well developed rough endoplasmatic reticulum (large arrow) system close to senescent arbuscule branches (ab). Note many vesicles (small arrowheads) in the space between host plasmalemma (large arrowhead) and collapsed fungal structures. 16. An arbuscule branch (ab) with nucleus (n) near to vacuolated arbuscule trunk (at). Bars $=2 \mu \mathrm{m}$. 

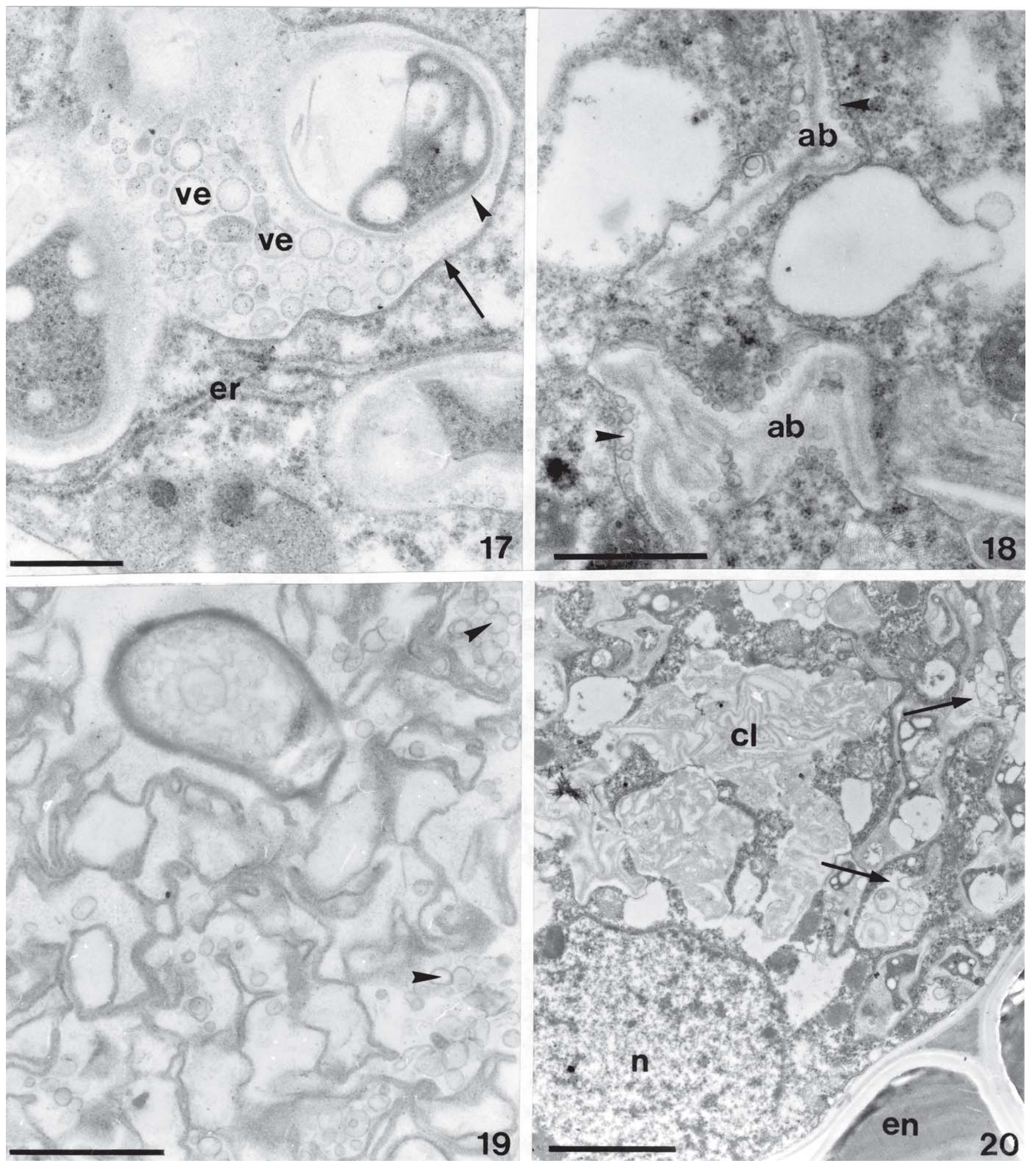

Figures 17-20. TEM of A. peregrina var. falcata mycorrhizas showing different stages of arbuscule senescence. 17. The space between host membrane (arrow), which sometimes seems to disappear, and fungal wall (arrowhead) is wider and many vesicles (ve) can be seen in this space. er = rough endoplasmatic reticulum. 18. More advanced stage of collapse of arbuscule branches (ab), which apparently are associated with vesicles (arrowheads). 19. Remains of arbuscule branches seems to aggregate. Some vesicles (arrowheads) still can be seen close to this material. 20. Residual hyphal masses form large clumps (cl) in host cytoplasm. Note that some arbuscule branches are in initial phase of collapse (arrows). $\mathrm{n}=$ nucleus; en = endodermis. Bars $=$ $0.5 \mu \mathrm{m}(17), 1 \mu \mathrm{m}(18-19), 2 \mu \mathrm{m}(20)$. 
probably, they are associated with fungus degradation. Near this collapsed arbuscules branches were observed a well-developed system of endoplasmatic reticulum, as seen in yellow poplar mycorrhiza (Kinden \& Brown 1976). This system also could be involved with the fungus degeneration.

The dramatic modifications of host cell architecture, such as position and morphology of nucleus, invagination of the plant plasmalemma, fragmentation of the vacuole and increase in the number of organelles observed in "angico do cerrado" are common features in AM symbiosis (Bonfante \& Perotto 1995). These cytological features are indicative of a metabolically active cell. In conclusion, A. peregrina var. falcata AM presented intermediate morphological type between Arum and Paris-type of mycorrhizas and the its ultrastructure was in agreement with pattern observed in arbuscular mycorrhizas of several plants.

Acknowledgements - We would like to thank to Fapesp (Fundação de Amparo à Pesquisa do Estado de São Paulo) for providing a grant to the first author (Process number 98/09517-4).

\section{References}

ALEXANDER, T., MEIER, R., TOTH, R. \& WEBER, H.C. 1988. Dynamics of arbuscule development and degeneration in mycorrhizas of Triticum aestivum L. and Avena sativa L. with reference to Zea mays L. New Phytologist 110:363-370.

APPEZZATO-DA-GLÓRIA, B. \& ESTELITA, M.E.M. 2000. The developmental anatomy of the subterranean system in Mandevilla ilustris (Vell.) Woodson and M. velutina (Mart. ex Stadelm.) Woodson (Apocynaceae). Revista Brasileira de Botânica 23:27-35.

BONFANTE, P. \& PEROTTO, S. 1995. Strategies of arbuscular mycorrhizal fungi when infecting host plants. New Phytologist 130:3-21.

BRUNDRETT, M.C., PICHÉ, Y. \& PETERSON, R.L. 1985. A developmental study of the early stages in vesiculararbuscular mycorrhiza formation. Canadian Journal of Botany 63:194-199.

CORDEIRO, L. \& BELTRATI, C.M. 1989. Estrutura e desenvolvimento de nódulos radiculares de Anadenanthera falcata Speg. Revista Brasileira de Botânica 12:61-70.

HOLLEY, J.D. \& PETERSON, R.L. 1979. Development of a vesicular-arbuscular mycorrhiza in bean roots. Canadian Journal of Botany 57:1960-1978.
KINDEN, D.A. \& BROWN, M.F. 1975. Electron microscopy of vesicular-arbuscular mycorrhizae of yellow poplar. II. Intracellular hyphae and vesicles. Canadian Journal of Microbiology 21:1768-1780.

KINDEN, D.A. \& BROWN, M.F. 1976. Electron microscopy of vesicular-arbuscular mycorrhizae of yellow poplar. IV. Host-endophyte interactions during arbuscular deterioration. Canadian Journal of Microbiology 22:64-75.

KRAUS, J.E. \& ARDUIN, M. 1997. Manual básico de métodos em morfologia vegetal. Edur, Seropédica.

LORENZI, H. 1994. Árvores brasileiras. Plantarum, Nova Odessa.

PAVIANI, T.I. 1974. Sobre a ocorrência de fibras gelatinosas em Plathymenia reticulata Benth. Ciência e Cultura 26:783-786.

PAVIANI, T.I. 1977. Estudo morfológico e anatômico de Brasilia sickii G.M. Barroso. II: Anatomia da raiz, do xilopódio e do caule. Revista Brasileira de Biologia 37:307-324.

PETERSON, R.L. \& BONFANTE, P. 1994. Comparative structure of vesicular-arbuscular mycorrhizas and ectomycorrhizas. Plant and Soil 159:79-88.

PHILLIPS, J.M. \& HAYMAN, D.S. 1970. Improved procedures for clearing roots and staining parasitic and vesiculararbuscular mycorrhizal fungi for rapid assesment of infection. Transactions of Britsh Mycological Society 55:158-161.

REATTO, A., CORREIA, J.R. \& SPERA, S.T. 1998. Solos do Bioma Cerrado. In Cerrado: ambiente e flora (S.M. Sano \& S.P. Almeida, eds.). Embrapa-CPAC, Planaltina, p.47-86.

RIZZINI, C.T. \& HERINGER, E.P. 1961. Underground organs of plants from some Brazilian savannas, with special reference to the xylopodium. Phyton 17:105-124.

SCANNERINI, S. \& BONFANTE, P. 1983. Comparative ultrastructural analysis of mycorrhizal associations. Canadian Journal of Botany 61:917-943.

SMITH, F.A. \& SMITH, S.E. 1997. Structural diversity in (vesicular)-arbuscular mycorrhizal symbioses. New Phytologist 137:373-388.

SMITH, S.E. \& SMITH, F.A. 1990. Structure and function of the interfaces in biotrophic symbioses as they relate to nutrient transport. New Phytologist 114:1-38.

SPURR, A.R. 1969. A low-viscosity epoxy resin embedding medium for electron microscopy. Journal of Ultrastructure Research 26:31-43.

THOMAZINI, L.I. 1974. Mycorrhiza in plants of the "Cerrado". Plant and Soil 41:707-711.

WIDDEN, P. 1996. The morphology of vesicular-arbuscular mycorrhizae in Clintonia borealis and Medeola virginiana. Canadian Journal of Botany 74:679-685. 